Theresia, Sri Marhanah dan Rosita: Perbandingan Persepsi Pengunjung Prospektif dan Pengunjung Pertama Kali Tentang Keunikan Daya Tarik Wisata Farmhouse Susu Lembang, Kabupaten Bandung Barat

\title{
PERBANDINGAN PERSEPSI PENGUNJUNG PROSPEKTIF DAN PENGUNJUNG PERTAMA KALI TENTANG KEUNIKAN DAYA TARIK WISATA FARMHOUSE SUSU LEMBANG, KABUPATEN BANDUNG BARAT
}

\author{
Theresia $^{(1)}$, Sri Marhanah ${ }^{(2)}$, Rosita $^{(3)}$ \\ (1)(2)(3) Program Studi Manajemen Resort \& Leisure \\ Universitas Pendidikan Indonesia \\ siambatontheresia@gmail.com
}

\begin{abstract}
ABSTRAK
Farmhouse Susu Lembang adalah tempat wisata baru yang menyuguhkan suasana Eropa yang nampak dari arsitektur bangunan dan atraksi yang disediakan. Nuansa Eropa tersebut mengundang pengunjung untuk mengabadikannya di media sosial, khususnya akun Instagram. Dari unggahan foto tersebut akan membentuk persepsi masyarakat yang belum pernah mengunjungi Farmhouse Susu Lembang. Penelitian ini bertujuan untuk memperoleh data informasi tentang perbandingan persepsi pengunjung prospektif dengan stimulus foto dan kalimat unggahan yang dilihat dari Instagram serta persepsi pengunjung yang sudah berkunjung pertama kali. Data yang digunakan dalam penelitian ini adalah data primer dengan kuesioner yang dibagikan kepada 200 responden, 100 responden yang belum pernah berkunjung dan 100 kuesioner lagi untuk responden yang sudah berkunjung sekali. Metode analisis yang digunakan dalam penelitian ini adalah uji beda dengan menggunakan paired sample t-test. Hasil penelitian ini menunjukkan pengunjung prospektif maupun pengunjung pertama kali setuju bahwa Farmhouse Susu Lembang adalah daya tarik wisata yang unik dan menarik. Perbedaannya terdapat pada skor total persepsi pengunjung prospektif, yang lebih besar daripada skor total persepsi pengunjung pertama kali.
\end{abstract}

Kata kunci: Persepsi, Pengunjung Prospektif, Pengunjung Pertama Kali

\section{COMPARISON PERCEPTIONS OF PROSPECTIVE VISITORS AND FIRST TIME VISITORS ABOUT UNIQUENESS OF FARMHOUSE SUSU LEMBANG TOURIST ATTRACTION, WEST BANDUNG REGENCY}

\begin{abstract}
Farmhouse Susu Lembang is a new tourist attractions that offer a European atmosphere that appears from the architecture of the buildings and attractions is provided. The European nuances makes the visitors want to capture them in social media, especially Instagram. From the photo uploaded will form the public perception that have never visited the Farmhouse Susu Lembang. This research aims to obtain data information about comparison perception of prospective visitors with stimulus pictures and sentences uploads that seen from Instagram and perception of visitors who have visited for the first time. The data used in this research is the primary data with a questionnaire that was distributed to 200 respondents, 100 respondents that have not been visited Farmhouse Susu Lembang and 100 respondents who have visited for the first time. Method of analysis used in this research is different from test by using paired samples t-test. The results of this research, show the prospective visitors or first time visitors agreed that the Farmhouse Susu Lembang is a unique tourist attraction and
\end{abstract}


interest. The difference is found in the score total perception of prospective visitors, which is much more than the score total perception of first time visitors.

Keywords: Perception, Prospective Visitors, First time visitors

\section{PENDAHULUAN}

Indonesia dengan kekayaan alam yang berlimpah dan kondisi alam tropisnya, mendukung Indonesia menjadi salah satu negara yang tepat untuk melakukan wisata. Hal tersebut didukung oleh kekayaan alam Indonesia mulai dari pantai, pegunungan, danau, sungai dan sumber daya alam lainnya. Melihat hal tersebut tak heran pihak pemerintah maupun non-pemerintahan berlomba-lomba menciptakan pariwisata yang terus berkembang sesuai perubahan zaman.

Perkembangan pariwisata pada suatu daerah sangat bergantung pada jumlah wisatawan yang datang dan juga pemanfaatan daya tarik wisata di daerah tujuan wisata tersebut. Hal tersebut pula lah yang dilakukan oleh pihak terkait bisnis pariwisata di kota Bandung. Pihak pemerintah atau nonpemerintah terus melihat kesempatan membangun pariwisata di kota Bandung. Usaha tersebut guna memanfaatkan daya tarik wisata kota kembang dalam meningkatkan jumlah kunjungan wisatawan. Perkembangan pariwisata di Bandung didorong oleh penetapan kota Bandung sebagai kota wisata dunia. Penetapan tersebut dilakukan di Beijing, China pada tanggal 25 September 2013 lalu, menurut Laporan Kinerja Instansi Dinas Budaya dan Pariwisata kota Bandung. Salah satu daerah di kota kembang yang terkenal dengan wisatanya adalah daerah Kabupaten Bandung Barat.

Kabupaten ini merupakan daerah subur dengan pemandangan yang indah dan kondisi geografis yang berbukit-bukit dengan ketinggian serta kemiringan yang variatif. Maka, tak heran daerah kabupaten Bandung Barat merupakan daerah yang ramai dikunjungi wisatawan. Dalam perkembangannya daerah tujuan wisata baru di Kabupaten Bandung Barat terus bermunculan. Hal tersebut dilakukan untuk mengantisipasi supaya tidak timbul kejenuhan pada wisatawan yang berkunjung ke daerah wisata di Kabupaten Bandung Barat.

Tempat wisata di Lembang pun terus berkembang dengan munculnya tempat wisata baru hampir disetiap tahunnya, seperti pada tahun 2007 wisata De'Ranch resmi di buka. Pada tahun 2009 muncul wisata Kampung Gajah, pada tahun 2010 muncul wisata Bandung Treetop. Pada tahun 2012 muncul dua wisata baru yang terkenal, yaitu Floating Market dan Dusun Bambu. Dan salah satu tempat wisata atau destinasi wisata yang paling terbaru adalah Farmhouse Susu Lembang yang dibuka akhir tahun 2015.

Farmhouse Susu Lembang resmi dibuka tepatnya pada tanggal 11 November 2015. Salah satu tempat wisata di Lembang ini baru beroperasi dan terkenal dikalangan masyarakat. Kesohorannya sudah menyebar hampir diseluruh tempat di Indonesia. Banyak berita dan ulasan tentang Farmhouse Susu Lembang ini yang siarkan di media sosial dan pertelevisian Indonesia. Hal yang mendorong begitu pesatnya pemberitaan dan wacana tentang tempat ini adalah karena atraksi yang disediakan di tempat tersebut. Atraksi yang menjadi sorotan dan paling diminati adalah adanya rumah The Hobbit.

Farmhouse Susu Lembang adalah sebuah tempat wisata yang menyuguhkan pemandangan dan suasana di Eropa. Desain dan penataan fasilitas dirancang untuk dijadikan sebagai photobooth yang nampak seperti berada di Eropa, udara yang sejuk di Lembang juga mendukung suasana tersebut. Hal itu merupakan salah satu penarik wisatawan untuk berkunjung ke Farmhouse Susu Lembang. Seperti menurut Richardson dan Fluker sebagai berikut. 
Theresia, Sri Marhanah dan Rosita: Perbandingan Persepsi Pengunjung Prospektif dan Pengunjung Pertama Kali Tentang Keunikan Daya Tarik Wisata Farmhouse Susu Lembang, Kabupaten Bandung Barat

Pull factors are those which 'pull' consumers towards a particular destination (e.g. a positive image, safety, atrraction, climate). Forms of tourism are among pull factors-the destination's offering to tourists (Richardson and Flucker, 2004 : 67).

Dari pendapat tersebut, menyatakan faktor pendorong mengunjungi suatu destinasi wisata salah satunya karena image atau citra yang positif dari suatu destinasi tersebut. Faktor penarik untuk dapat berkunjung ke Farmhouse adalah maraknya pengguna media sosial, salah satunya Instagram. Banyak yang tertarik dengan background bernuansa Eropa untuk dapat dipost di Intagram mereka. Faktor penarik lain adalah salah satu desain background di Farmhouse yang menyerupai seperti bentuk rumah yang ada di film berjudul The Hobbit.

Foto-foto suasana Farmhouse Susu Lembang yang indah bernuansa Eropa tersebut banyak diunggah di media sosial, khususnya Instagram. Aplikasi yang banyak dimiliki oleh masyarakat hampir di semua kalangan ini, memiliki andil dalam membentuk persepsi pengunjung. Foto-foto yang di unggah pada akun mereka yang sudah berkunjung ke Farmhouse menjadikan rangsang bagi para calon pengunjung. Rangsang berupa gambar yang ditangkap melalui indera pengelihatan tersebut memotivasi pengunjung untuk datang ke Farmhouse.

Dari foto dan kalimat unggahan tersebut akan muncul beberapa kalimat negatif maupun positif yang menunjukkan, pengunjung yang menginterpretasikan rangsang yang di terima dari indera mereka (media sosial, khususnya Instagram) kurang sesuai dengan kenyataan dan pengalaman yang dialami di Farmhouse.

Media sosial membangun citra Farmhouse dan membentuk persepsi di masyarakat, dari persepsi tersebut timbulah ekspektasi yang memotivasi pengunjung untuk datang ke Farmhouse. Dan pada kenyataan yang dialami pengunjung, terjadi perbedaan dengan persepsi dan ekspektasi mereka.
Citra dari Farmhouse menjadi penarik bagi masyarakat untuk berkunjung. Persepsi calon pengunjung akan timbul setelah membaca atau melihat informasi tentang destinasi yang akan dikunjunginya. Dalam upaya mengenali objek wisata yang akan dikunjunginya, wisatawan akan mempelajari informasi-informasi yang diperoleh melalui iklan, buku, media sosial maupun kerabat.

Informasi tersebut akan disesuaikan dengan tujuan dan keinginan dalam berwisata. Maka akan terbentuk persepsi dari proses mempelajari informasi-informasi tersebut. Persepsi dapat timbul dari banyak indikator yang ditangkap oleh indera setiap individu, seperti nama suatu destinasi tersebut. Destinasi ini bernama Farmhouse Susu Lembang. Dari namanya, wisatawan dapat mempelajari bahwa destinasi ini merupakan destinasi dengan wisata perkebunan, karena unsur kata 'Farm' pada namanya yang berarti kebun, perkebunan, ladang pertanian dan ladang. Adanya unsur kata 'susu' juga menimbulkan persepsi bahwa mungkin ada kegiatan memeras susu sapi dan tersedia susu sapi di tempat tersebut.

Suatu objek wisata harus meningkatkan kualitas objek menjadi lebih baik guna mendapatkan persepsi positif.

Untuk mengetahui seberapa besar keinginan pasar, diperlukan analisis persepsi. Persepsi terhadap kuliatas atraksi yang menjadi tolok ukur untuk melihat tingkat mutu suatu daya tarik wisata. Penelitian ini lebih menekankan pengamatan terhadap persepsi wisatawan sebelum dan sesudah berkunjung terhadap kemenarikan dan keuinikan daya tarik wisata di Farmhouse Lembang, Kabupaten Bandung Barat. Pengukuran yang akan diamati dalam penelitian ini adalah hasil dari persepsi wisatawan melalui gambar atau foto yang di unggah di akun instagram beserta kalimatnya.

Meningkatnya kunjungan wisata, salah satu faktornya adalah pengalaman wisata dari kunjungan sebelumnya. Persepsi pengunjung terhadap daya tarik wisata yang ada di Farmhouse membentuk pengalaman bagi pengunjung tersebut untuk memutuskan 
berkunjung kembali. Dari pengalaman beberapa pengunjung yang sudah mengunjungi Farmhouse timbul ketidakpuasan karena kurangnya atraksi sehingga aktivitas yang dilakukan di tempat itu juga terbatas. Maka, pentingnya sebuah pengalaman akan berdampak pada keinginan wisatawan untuk menjadi repeat buyers. Persepsi wisatawan terhadap daya tarik wisata dapat berakumulasi menjadi kekuatan besar seseorang menentukan destinasi yang akan dikunjungi.

Berdasarkan uraian fenomena di atas, maka pentingnya memperhatikan persepsi wisatawan terhadap tempat wisata Farmhouse Susu Lembang untuk menciptakan pengunjung yang loyal dan mengetahui keinginan pasar di masa depan, melalui sebuah studi. Untuk mengetahui persepsi calon pengunjung (Pengunjung Prospektif) dan pengunjung yang sudah berkunjung sekali (First Time Visitors), akan diketahui adanya perbedaan persepsi sebelum dan setelah berkunjung dari nilai keunikan Farmhouse Susu Lembang.

Tujuan dari penelitian ini adalah untuk mengetahui persepsi pengunjung prospektif dan pertama kali tentang keunikan Farmhouse Susu Lembang dan perbedaan persepsi keduanya. Hasil dari penelitian ini dapat digunakan oleh pihak pengelola untuk mengetahui nilai keunikan yang di miliki Farmhouse Susu Lembang.

\section{LANDASAN TEORI}

Menurut Walgito (2007: 8) persepsi merupakan proses pengorganisasian, penginterpretasian terhadap rangsang yang diterima oleh organisme atau individu sehingga menjadi sesuatu yang berarti, dan merupakan aktivitas yang terhubung dalam diri individu dengan berbagai macam bentuk. Informasi-informasi tersebut merupakan rangsang yang diterima oleh individu.

Menurut Ismayanti (2010), membentuk persepsi positif tentang daerah tujuan wisata dengan berbagai atribut-atribut pariwisatanya pada diri wisatawan, menjadi salah satu kunci untuk menjamin perkembangan suatu destinasi wisata. Untuk menciptakan persepsi yang positif maka, suatu objek wisata dituntut untuk memenuhi keinginan wisatawan (Pitana dan Gayatri, 2005).

\section{METODE}

Lokasi penelitian dilakukan di Farmhouse Susu Lembang yang beralamat di di J1. Raya Lembang no. 108, Gudang Kahuripan, Kabupaten Bandung Barat. Populasi dalam penelitian ini adalah seluruh pengunjung Farmhouse Susu Lembang pada bulan Februari 2016. Sampel di ambil menggunakan teknik accidential sampling, dimana dalam pengambilan sampelnya tidak ditetapkan terlebih dahulu namun langsung mengumpulkan data dari unit sampling yang ditemuinya (Nawawi, 2001). Sampel berjumlah 100 orang yang digunakan untuk pengunjung prospektif maupun pengunjung pertama kali.

Variabel dalam penelitian ini adalaah persepsi. Jenis penelitiannya adalah deskriptif kuantitatif dengan analisis datanya menggunakan analisis Uji $\mathrm{T}$ dua sampel berpasangan (Paired Sampel T-Test), untuk membuktikan hipotesis penelitian ini, yaitu:

Hipotesis 1

Ho: Tidak ada perbedaan persepsi pengunjung prospektif melalui rangsang foto dengan persepsi pengunjung pertama kali (first time visitors).

Ha: Ada perbedaan persepsi pengunjung prospektif melalui rangsang kalimat unggahan dengan persepsi pengunjung pertama kali (first time visitors).

Hipotesis 2

Ho: Tidak ada perbedaan persepsi pengunjung prospektif melalui rangsang kalimat unggahan dengan persepsi pengunjung pertama kali (first time visitors).

Ha: Ada perbedaan persepsi pengunjung prospektif melalui rangsang kalimat unggahan dengan persepsi pengunjung pertama kali (first time visitors). 
Theresia, Sri Marhanah dan Rosita: Perbandingan Persepsi Pengunjung Prospektif dan Pengunjung Pertama Kali Tentang Keunikan Daya Tarik Wisata Farmhouse Susu Lembang, Kabupaten Bandung Barat

Pengolahan data dalam penelitian ini menggunakan tabulasi data, seperti pengelompokkan foto dan kalimat unggahan, serta garis kontinum. Penelitian deskriptif merupakan penelitian yang dilakukan untuk mengetahui nilai variabel mandiri, baik satu variabel maupun lebih Sugiyono (2008 hlm 11).

Dengan menggunakan metode penelitian deskriptif tersebut, maka dapat diperoleh deskripsi mengenai, sebagai berikut:

a. Gambaran mengenai persepsi wisatawan pra berkunjung ke Farmhouse Susu Lembang.

b. Gambaran mengenai persepsi wisatawan pasca berkunjung ke Farmhouse Susu Lembang.

c. Deskripsi perbedaan antara persepsi wisatawan pra dan pasca kunjungan ke Farmhouse Susu Lembang.

Pengumpulan data dilakukan dengan menyebarkan angket kepada responden.

\section{HASIL DAN PEMBAHASAN}

Farmhouse Susu Lembang merupakan salah satu tempat wisata terbaru di Bandung dan paling diminati sejak awal dibukanya pada tanggal 11 November 2015. Tempat wisata dengan luas \pm 2 Hektare ini merupakan tempat wisata yang unik dengan mengambil tema Eropa pada setiap desain arsitekturnya. Tempat ini dibuat oleh pemiliknya, yaitu Perry Tristianto untuk menjadi tempat wisata satu-satunya di kota Bandung yang bertemakan Eropa pada desain arsitekturnya.

Tempat wisata ini buka setiap hari, pada hari kerja buka sejak pukul 09.00 sampai 21.00, sedangkan pada akhir pekan buka mulai pukul 09.00 sampai 23.00. Biaya tiket masuk ke tempat wisata ini adalah sebesar Rp 20.000. Tempat ini juga memiliki lahan parkir yang lumayan luas, dapat menampung hingga 1000 kendaraan, baik kendaraan motor, mobil, shuttle dan bus. Biaya parkir untuk kendaraan motor adalah sebesar Rp 5.000, mobil Rp 10.000, mobil travel atau shuttle Rp. 20.000 dan bus sebesar Rp 50.000.
Pemberian nama Farmhouse Susu Lembang memiliki maksud dan arti tertentu. Pemberian kata susu pada tempat ini ada hubungannya dengan pelayanan yang ditawarkan, yaitu berupa pemberian satu cup susu murni gratis dengan syarat menukarkan tiket masuk Farmhouse Susu Lembang yang didapat setelah masuk ke Farmhouse. Tiket masuk tersebut selain dapat ditukarkan dengan susu murni, pilihan lainnya dapat ditukar dengan sosis bakar.

Atraksi utama (main attraction) yang dimiliki tempat ini adalah rumah The Hobbit. Rumah the Hobbit menjadi sangat dikenal karena kehadirannya di film fiksi berjudul The Hobbit. Replika rumah The Hobbit yang diketahui berada di Lembang, Kabupaten Bandung Barat ini seakan sontak menarik perhatian masyarakat untuk mengetahui keberadaan tempat tersebut dan mengunjungi tempat itu.

Rumah The Hobbit di Farmhouse Susu Lembang ini bukanlah satu-satunya daya tarik yang disuguhkan di tempat ini, atraksi lainnya seperti curug (air terjun) buatan, sumur buatan, gembok cinta, taman bunga, taman sayuran (vegetable garden), pagar gembok cinta dan Petting Zoo juga memeriahkan suasana di Farmhouse. Hewan yang ada di tempat ini juga unik, karena binatang yang dipertontonkan adalah binatang-binatang peliharaan, seperti kelinci, burung-burung, landak kecil, domba-domba dan reptil seperti iguana dan kadal. Hewanhewan dipertunjukkan di tempat ini guna mendukung nama 'Farmhouse', yang memiliki arti 'rumah petani', dimana rumah petani biasanya memiliki hewan-hewan peliharaan atau hewan ternak.

Tidak hanya daya tarik tersebut yang mendorong wisatawan untuk berkunjung ke Farmhouse Susu Lembang, akan tetapi fasilitas yang melengkapinya, seperti coffee shop, juice bar, photobooth, restoran, ruang serba guna, retail/ FO, souvenir shop dan penyewaan baju ala none Belanda. Tempat ini merupakan tempat yang memiliki nilai artistik di setiap sudutnya. Pada awal masuk area Farmhouse saja, pengunjung sudah 
dapat melihat tempat unik berbentuk botol susu dengan ukuran yang besar dimana tempat itu merupakan tempat para pengunjung dapat menukarkan tiket masuk mereka dengan susu. Selanjutnya pegunjung akan melihat banyak hal cantik lainnya, yaitu jalan yang disebelah kanan-kirinya dibatasi oleh akar tanaman. Setiap sudutsudut tersebut merupakan tempat yang cocok dijadikan untuk berfoto ria dilengkapi beberapa tempat duduk dari kayu berpelitur yang nyaman.

Bagi pengunjung yang memiliki hobi foto atau yang lebih dikenal saat ini berselfie, beberapa spot di tempat ini bisa dijadikan sebagai latar berfoto selain di rumah The Hobbit, di antaranya: pekarangan tempat menyewa kostum Eropa (Rp 50.000 per 2 jam), lapangan alun-alun, gedung serba guna, taman bunga, restoran dan sungai serta gembok cinta. Di souvenir shop pun pengunjung bisa berbelanja barang-barang kerajinan tangan dan pernak-pernik ala Eropa dan Indonesia, seperti mug, hiasan dan tas-tas.

Karena indahnya Farmhouse Susu Lembang untuk tempat berfoto, menimbulkan ramainya bermunculan foto beserta kalimat unggahannya di media sosial, terutama Instagram. Jenis-jenis foto yang di unggah dapat dilihat dari gambar 1 . sebagai berikut:

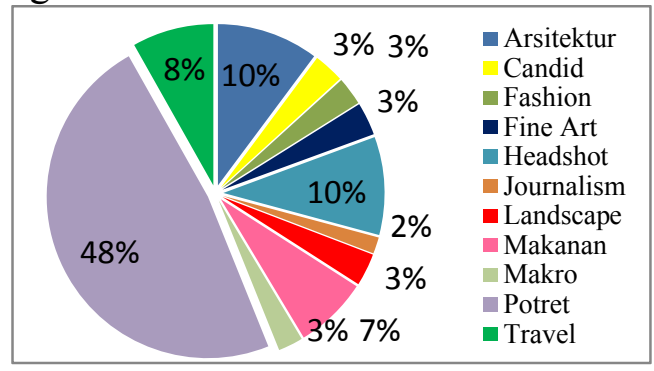

Gambar 1. Jenis Foto Unggahan Sumber: Olahan penulis (2016)
Gambar 1. tersebut merupakan hasil dari pengumpulan foto di Instagram dengan hashtag \#farmhoususulembang pada bulan Maret 2016 sebanyak 248 foto. Kemudian dibagi dalam 11 jenis foto, yang menunjukkan banyaknya foto potret, dimana foto potret ini merupakan foto yang berlatarbelakang rumah The Hobbit.

Jenis kalimat unggahan juga dikumpulkan dan dipersentasikan dalam beberapa jenis kalimat unggahan sebagai berikut:

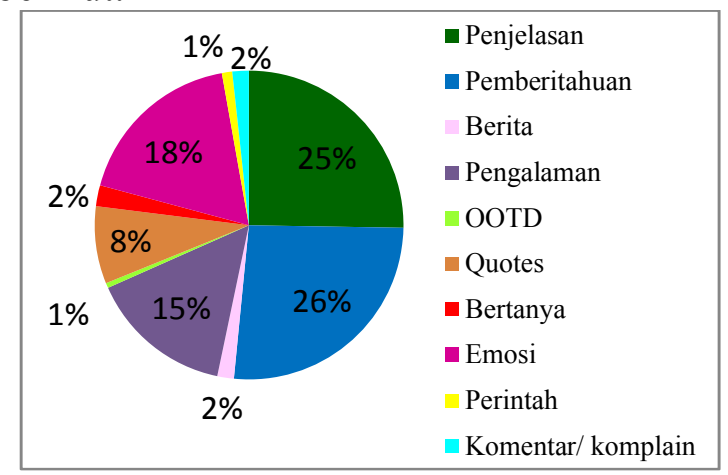

Gambar 2. Jenis Kalimat Unggahan Sumber: Olahan penulis (2016)

Jenis kalimat unggahan yang paling banyak adalah jenis kalimat permberitahuan sebanyak $26 \%$ dari semua kalimat unggahan foto sebanyak 178 kalimat.

Dari foto dan kalimat unggahan tersebut diambil yang paling banyak untuk dijadikan rangsang bagi responden prospektif pada kuesioner. Responden prospektif akan menilai dari foto dan kalimat unggahan yang disajikan dalam kuesioner.

Dari hasil kuesioner pengunjung prospektif dketahui nilai keunikan yang diberikan untuk Farmhouse Susu Lembang melalui foto dan kalimat ungghan tersebut. Hasil dari penilaian pengunjung prospektif melalui rangsang foto dapat dilihat pada tabel 2 . sebagai berikut:

Tabel 2. Rekapitulasi skor nilai Persepsi Pengunjung prospektif melalui rangsang foto

\begin{tabular}{clccccccccc}
\hline \multirow{2}{*}{ No } & Sub Variabel & Pernyataan & $\mathbf{1}$ & $\mathbf{2}$ & $\mathbf{3}$ & $\mathbf{4}$ & $\mathbf{5}$ & Jumlah & $\begin{array}{c}\text { Total } \\
\text { Skor }\end{array}$ & Ket \\
\hline \multirow{3}{*}{1} & $\begin{array}{l}\text { Penyerapan } \\
\text { terhadap } \\
\begin{array}{l}\text { rangsangan } \\
\text { atau objek }\end{array}\end{array}$ & Gambaran Farmhouse yang Unik & 2 & 3 & 22 & 56 & 17 & 100 & 383 \\
\cline { 2 - 9 } & Anggapan Farmhouse yang Unik dan Menarik & 2 & 2 & 21 & 55 & 20 & 100 & 389 \\
\cline { 2 - 9 } & $\%$ & 2 & 2 & 21 & 55 & 20 & 100 & 77,8 \\
\hline
\end{tabular}


Theresia, Sri Marhanah dan Rosita: Perbandingan Persepsi Pengunjung Prospektif dan Pengunjung Pertama Kali Tentang Keunikan Daya Tarik Wisata Farmhouse Susu Lembang, Kabupaten Bandung Barat

\begin{tabular}{|c|c|c|c|c|c|c|c|c|c|c|}
\hline & $\begin{array}{l}\text { dari luar } \\
\text { individu }\end{array}$ & $\begin{array}{l}\text { Kesan positif tentang Farmhouse yang Unik } \\
\text { dan Menarik }\end{array}$ & 2 & - & 24 & 53 & 21 & 100 & 391 & \\
\hline & & $\%$ & 2 & - & 24 & 53 & 21 & 100 & & \\
\hline \multirow{4}{*}{2} & \multirow{4}{*}{$\begin{array}{l}\text { Pengertian } \\
\text { atau } \\
\text { Pemahaman }\end{array}$} & $\begin{array}{l}\text { Mengetahui bahwa Farmhouse adalah tempat } \\
\text { yang unik dan menarik }\end{array}$ & 2 & 5 & 36 & 48 & 9 & 100 & 357 & \multirow{4}{*}{ Setuju } \\
\hline & & $\%$ & 2 & 5 & 36 & 48 & 9 & 100 & 71,4 & \\
\hline & & $\begin{array}{l}\text { Mengetahui benar bahwa Farmhouse adalah } \\
\text { tempat yang unik dan menarik }\end{array}$ & 2 & 3 & 42 & 43 & 10 & 100 & 356 & \\
\hline & & $\%$ & 2 & 3 & 42 & 43 & 10 & 100 & 71,2 & \\
\hline \multirow[t]{4}{*}{3} & $\begin{array}{l}\text { Penilaian dan } \\
\text { Evaluasi }\end{array}$ & $\begin{array}{l}\text { Penilaian bahwa Farmhouse adalah daya } \\
\text { tarik wisata yang unik dan menarik }\end{array}$ & 4 & 3 & 22 & 48 & 23 & 100 & 383 & \multirow{2}{*}{ Setuju } \\
\hline & & $\%$ & 4 & 3 & 22 & 48 & 23 & 100 & 76,6 & \\
\hline & & Total Skor & & & & & & & 2259 & \\
\hline & & $\%$ & & & & & & & 75,3 & \\
\hline
\end{tabular}

Sumber: Olahan penulis (2016)

Nilai indeks maksimum

$$
\begin{aligned}
& =\text { skala tertinggi } \\
& \times \text { jumlah pertanyaan } \\
& \times \text { responden } \\
& =5 \times 5 \times 100 \\
& =3000
\end{aligned}
$$

Nilai indeks minimum

$$
\begin{aligned}
& =\text { skala terendah } \\
& \times \text { jumlah pertanyaan } \\
& \times \text { responden } \\
& =6 \times 1 \times 100 \\
& =600
\end{aligned}
$$

Jarak interval

$$
\begin{aligned}
& =\frac{(\text { nilai maksimum }- \text { nilai minimum })}{5} \\
& =\frac{(3000-600)}{5} \\
& =480 \\
& =16 \%
\end{aligned}
$$

Persentase skor $=$ skor total $/$ nilai maks. $\times 100 \%$

$$
\begin{aligned}
& =2259 / 3000 \times 100 \% \\
& =75,3 \%
\end{aligned}
$$

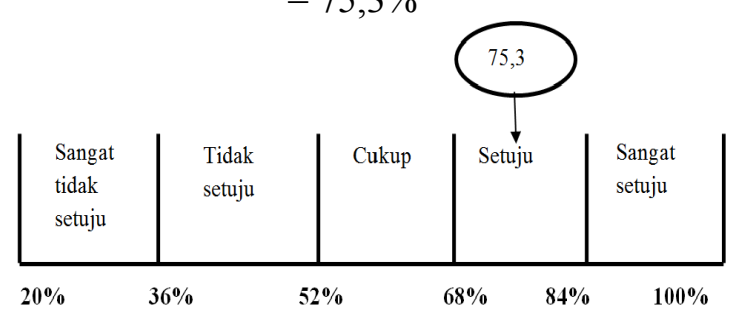

\section{Gambar 3. Garis Kontinum Rekapitulasi Persepsi Pengunjung Prospektif Dengan Rangsang Foto \\ Sumber: Olahan penulis (2016)}

Nilai persepsi pengunjung prospektif melalui gambaran, anggapan dan kesan positif terhadap daya tarik wisata Farmhouse Susu Lembang dirata-ratakan sehingga menghasilkan nilai persepsi. Nilai

\begin{tabular}{|c|c|c|c|c|c|c|c|c|c|c|}
\hline No & Sub Variabel & Pernyataan & 1 & 2 & 3 & 4 & 5 & Jumlah & $\begin{array}{l}\text { Total } \\
\text { Skor }\end{array}$ & Ket \\
\hline \multirow{4}{*}{1} & \multirow{4}{*}{$\begin{array}{l}\text { Penyerapan } \\
\text { terhadap } \\
\text { rangsangan } \\
\text { atau objek dari } \\
\text { luar individu }\end{array}$} & Gambaran Farmhouse yang Unik & 1 & 2 & 11 & 60 & 26 & 100 & 408 & \multirow{4}{*}{ Setuju } \\
\hline & & $\%$ & 1 & 2 & 11 & 60 & 26 & 100 & 81,6 & \\
\hline & & $\begin{array}{l}\text { Anggapan Farmhouse yang Unik dan } \\
\text { Menarik }\end{array}$ & 1 & 1 & 17 & 55 & 26 & 100 & 404 & \\
\hline & & $\%$ & 1 & 1 & 17 & 55 & 26 & 100 & 80,8 & \\
\hline
\end{tabular}
persepsi melalui stimulus foto tersebut sebesar 75,3\% yang berada pada garis kontinum setuju. Maka, pengunjung prospektif setuju bahwa Farmhouse Susu Lembang adalah daya tarik wisata yang unik atau menarik.

Pengunjung prospektif juga mendapatkan rangsang melalui kalimat unggahan sebagai tahap mempersepsikan Farmhouse Susu Lembang dalam penilaian keunikannya. Berikut rekapitulasi persepsi pengunjung prospektif melalui rangsang foto pada tabel 3:

Tabel 3. Rekapitulasi Skor Nilai Persepsi Pengunjung Prospektif Melalui Rangsang Kalimat Unggahan 




Sumber: Olahan penulis (2016)

Nilai indeks maksimum

$$
\begin{aligned}
& =\text { skala terting } i \\
& \times \text { jumlah pertanyaan } \\
& \times \text { responden } \\
& =5 \times 5 \times 100 \\
& =3000
\end{aligned}
$$

Nilai indeks minimum

$$
=\text { skala terendah }
$$

$\times$ jumlah pertanyaan

$\times$ responden

$$
=6 \times 1 \times 100
$$

$$
=600
$$

Jarak interval

$$
\begin{aligned}
& =\frac{(\text { nilai maksimum }- \text { nilai minimum })}{5} \\
& =\frac{(3000-600)}{5}
\end{aligned}
$$



$=480$

$=16 \%$

Persentase skor $=$ skor total $/$ nilai maks. $\mathrm{x} 100 \%$

$$
\begin{aligned}
& =2402 / 3000 \times 100 \% \\
& =80,1 \%
\end{aligned}
$$

Maka, secara keseluruhan persepsi pengunjung prospektif terhadap daya tarik wisata Farmhouse Susu Lembang, melalui stimulus kalimat adalah setuju bahwa

\begin{tabular}{|c|c|c|c|c|c|c|c|c|c|c|}
\hline No & Sub Variabel & Pernyataan & 1 & 2 & 3 & 4 & 5 & Jumlah & $\begin{array}{l}\text { Total } \\
\text { Skor }\end{array}$ & Ket \\
\hline \multirow{5}{*}{1} & \multirow{5}{*}{$\begin{array}{l}\text { Penyerapan } \\
\text { terhadap } \\
\text { rangsangan } \\
\text { atau objek dari } \\
\text { luar individu }\end{array}$} & Gambaran Farmhouse yang Unik & - & 5 & 31 & 52 & 12 & 100 & 371 & \multirow{5}{*}{ Setuju } \\
\hline & & $\%$ & - & 5 & 31 & 52 & 12 & 100 & 74,2 & \\
\hline & & $\begin{array}{l}\text { Anggapan Farmhouse yang Unik dan } \\
\text { Menarik }\end{array}$ & - & 9 & 33 & 52 & 6 & 100 & 355 & \\
\hline & & $\%$ & - & 9 & 33 & 52 & 6 & 100 & 71 & \\
\hline & & Kesan positif tentang Farmhouse yang Unik & - & 8 & 32 & 53 & 7 & 100 & 359 & \\
\hline
\end{tabular}
Farmhouse merupakan daya Tarik Wisata yang unik dan menarik, dengan nilai sebesar 2402 dengan persentase sebesar $80 \%$.

Untuk mengetahui persepsi pengunjung pertama kali, dilakukan penilaian juga terhadap pengunjung tersebut. Berikut tabel rekapitulasi skor penilaian persepsi Farmhouse Susu Lembang oleh pengunjung pertama kali:

Tabel 4.Tabel Rekapitulasi Persepsi Pengunjung Pertama Kali Terhadap Farmhouse Susu Lembang 
Theresia, Sri Marhanah dan Rosita: Perbandingan Persepsi Pengunjung Prospektif dan Pengunjung Pertama Kali Tentang Keunikan Daya Tarik Wisata Farmhouse Susu Lembang, Kabupaten Bandung Barat

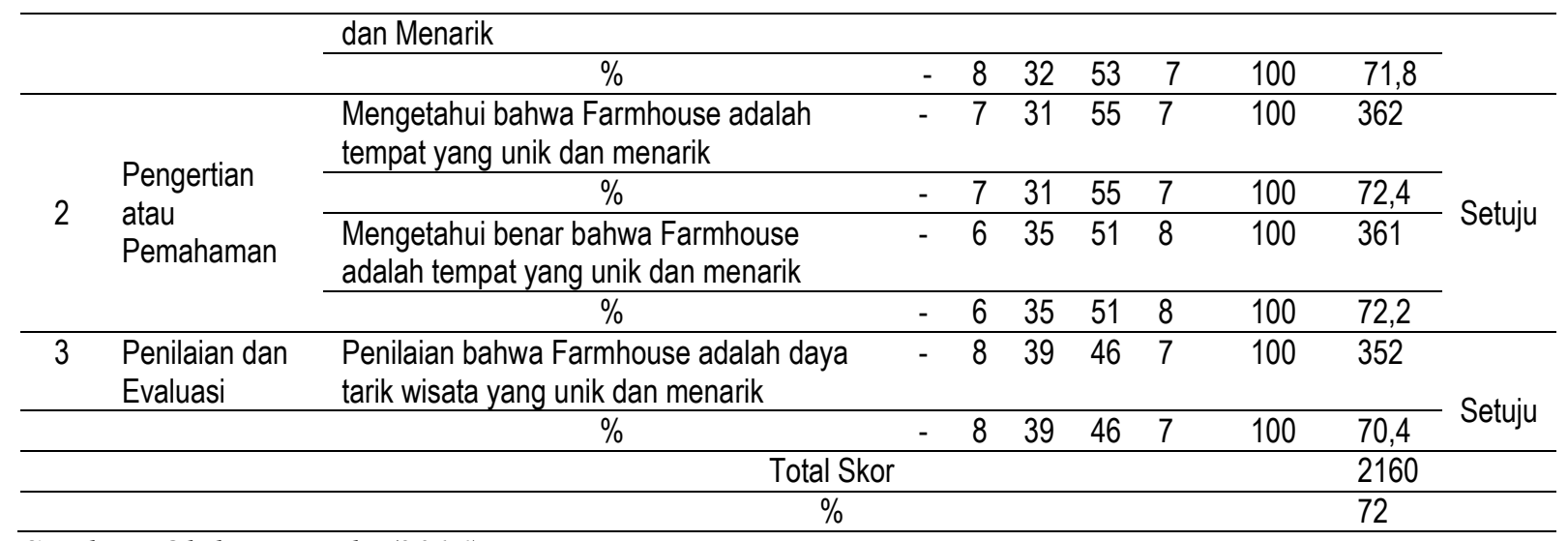

Sumber: Olahan penulis(2016)

Nilai indeks maksimum

$$
\begin{aligned}
& =\text { skala terting } i \\
& \times \text { jumlah pertanyaan } \\
& \times \text { responden } \\
& =5 \times 5 \times 100 \\
& =3000
\end{aligned}
$$

Nilai indeks minimum

= skala terendah

$\times$ jumlah pertanyaan

$\times$ responden

$=6 \times 1 \times 100$

$=600$

Jarak interval

$$
\begin{aligned}
& =\frac{(\text { nilai maksimum }- \text { nilai minimum })}{5} \\
& =\frac{(3000-600)}{5} \\
& =480 \\
& =16 \%
\end{aligned}
$$

Persentase skor $=$ skor total $/$ nilai maks. $\mathrm{x} 100 \%$ $=2160 / 3000 \times 100 \%$ $=72 \%$

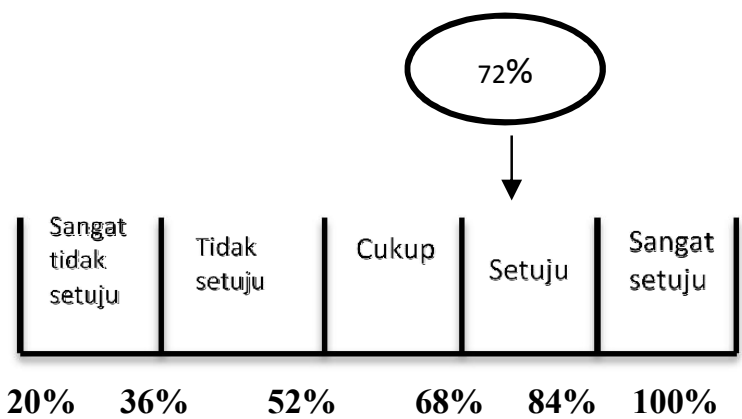

Gambar 5. Garis Kontinum Rekapitulasi Persepsi Pengunjung Pertama Kali Terhadap Farmhouse Susu Lembang Sumber: Olahan penulis (2016)
Maka, secara keseluruhan persepsi pengunjung pertama kali terhadap daya tarik wisata Farmhouse Susu Lembang adalah setuju, dengan nilai sebesar 2160 dengan persentase sebesar 72\%. Maka persepsi pengunjung pertama kali adalah setuju bahwa Farmhouse Susu Lembang adalah daya tarik wisata yang unik dan menarik.

Dari semua penilaian terhadap daya tarik wisata Farmhouse Susu Lembang diketahui bahwa pengunjung prospektif melalui rangsang foto dan kalimat unggahan serta pengunjung pertama kali setuju bahwa Farmhouse adalah daya tarik wisata yang unik dan menarik. Terdapat sedikit selisih pada persepsi melalui foto dan kalimat unggahan, dimana total skor persepsi melalui rangsang foto sebesar $75,3 \%$, sedangkan melalui rangsang kalimat $80,1 \%$

Hal tersebut menunjukkan bahwa persepsi pengunjung prospektif condong lebih setuju pada kalimat yang diunggah daripada pada foto yang ditunjukkan pada kuesioner. Persepsi pengunjung setelah berkunjung sekali (first time visitors) adalah sebesar 72\%. Pada hasil tersebut diketahui bahwa persepsi pengunjung pertama kali lebih kecil daripada persepsi pengunjung prospektif, baik melalui rangsang foto maupun rangsang kalimat. Maka, terdapat perbedaan antara persepsi pengunjung yang belum berkunjung/calon pengunjung/ pengunjung prospektif dengan persepsi setelah berkunjung pertama kali.

Hasil perhitungan uji $\mathrm{T}$ pada hasil penjumlahan skor total persepsi pengunjung 
prospektif dengan rangsang foto dan persepsi pengunjung pertama kali (first time visitors) dapat dilihat pada tabel 5, sebagai berikut:

Tabel 5. Hasil Uji T perbandingan pengunjung prospektif dengan rangsang foto dan first time visitors

\begin{tabular}{ccc}
\hline & $\begin{array}{c}\text { Persepsi } \\
\text { Prospektif } \\
\text { Visitors } \\
\text { (rangsang foto) }\end{array}$ & $\begin{array}{c}\text { Persepsi First } \\
\text { Time Visitors }\end{array}$ \\
\hline $\begin{array}{c}\text { Jumlah } \\
\text { sampel (n) }\end{array}$ & 100 & 100 \\
\hline $\begin{array}{c}\text { Standard } \\
\text { Deviasi (S) }\end{array}$ & 6,252 & \\
\hline Rata-rata ( $\boldsymbol{\pi})$ & 23,08 & 20,7 \\
\hline t-hitung & \multicolumn{3}{c}{3,807} \\
\hline t-tabel & \multicolumn{3}{c}{1,984} \\
\hline p-value & 0,001 & \\
\hline
\end{tabular}

Sumber: Olahan penulis (2016)

Berdasarkan uji $\mathrm{T}$ pada tabel 5, menggambarkan bahwa data nilai persepsi pengunjung prospektif (rangsang foto) dan persepsi pengunjung pertama kali mendapat nilai t-hitung sebesar 3,807. Nilai t-tabel pada $\mathrm{df}=99$ pada derajat kepercayaan $95 \%$ diperoleh sebesar 1,984 dan dengan p-value sebesar 0,001. Hal ini menunjukkan bahwa, Ho ditolak dan disimpulkan bahwa terdapat perbedaan persepsi pengunjung prospektif melalui rangsang foto dengan persepsi pengunjung pertama kali. Dengan perbedaan yang signifikan.

Dilakukan juga uji $\mathrm{T}$ sebagai pembuktian hipotesis penelitian terhadap perbandingan persepsi sebelum berkunjung (melalui rangsang kalimat unggahan) dan sesudah berkunjung. Hasil perhitungan nilai dari penjumlahan skor total persepsi pengunjung prospektif dengan rangsang foto, dan persepsi pengunjung pertama kali (first time visitors) dapat dilihat pada tabel 6, sebagai berikut:

Tabel 6.

Hasil Uji T Perbandingan Pengunjung

Prospektif Dengan Rangsang Kalimat

Unggahan dan First Time Visitors

\begin{tabular}{ccc}
\hline & $\begin{array}{c}\text { Persepsi } \\
\text { Prospektif Visitors } \\
\text { (rangsang foto) }\end{array}$ & $\begin{array}{c}\text { Persepsi } \\
\text { First Time } \\
\text { Visitors }\end{array}$ \\
\hline $\begin{array}{c}\text { Jumlah sampel } \\
\text { (n) }\end{array}$ & 100 & 100 \\
\hline $\begin{array}{c}\text { Standard } \\
\text { Deviasi (S) }\end{array}$ & 6,252 & \\
\hline Rata-rata ( $\boldsymbol{\pi})$ & 23,08 & 20,7 \\
\hline t-hitung & 3,807 & \\
\hline t-tabel & \multicolumn{3}{|c}{1,984} \\
\hline p-value & \multicolumn{2}{|c}{0,001} \\
\hline
\end{tabular}

Sumber: Olahan penulis (2016)

Berdasarkan uji $\mathrm{T}$ pada tabel 6, menggambarkan bahwa data nilai persepsi pengunjung prospektif (rangsang kalimat unggahan) dan persepsi pengunjung pertama kali mendapat nilai t-hitung sebesar 3,991. Nilai t-tabel pada df $=99$ pada derajat kepercayaan 95\% diperoleh sebesar 1,984 dan dengan p-value sebesar 0,001. Ho ditolak dan disimpulkan bahwa terdapat perbedaan persepsi pengunjung prospektif melalui rangsang kalimat unggahan dengan persepsi pengunjung pertama kali. Dengan perbedaan yang signifikan.

Pada rata-rata persepsi pengunjung prospektif dengan rangsang, terdapat perbedaan. Jumlah rata-rata persepsi melalui rangsang foto lebih kecil di banding dengan jumlah rata-rata persepsi melalui rangsang kalimat.

Skor hasil persepsi pengunjung prospektif melalui rangsang foto lebih besar daripada skor persepsi pengunjung pertama kali. Menunjukkan bahwa persepsi awal yang ditangkap melalui foto lebih baik daripada kenyataan setelah berkunjung. Begitu pula dengan skor total persepsi pengunjung prospektif dengan rangsang kalimat, dimana skornya lebih besar dibandingkan persepsi pengunjung pertama kali. Dari kedua total skor tersebut skor total melalui rangsang kalimatlah yang lebih besar. Maka, persepsi yang didapat melalui rangsang kalimat lebih sesuai dengan kenyataan yang dialami pengunjung pertama kali sehingga penilaiannya pun lebih baik.

Namun perbedaan tersebut masih berada pada garis kontinum setuju bahwa 
Theresia, Sri Marhanah dan Rosita: Perbandingan Persepsi Pengunjung Prospektif dan Pengunjung Pertama Kali Tentang Keunikan Daya Tarik Wisata Farmhouse Susu Lembang, Kabupaten Bandung Barat

daya tarik Farmhouse Susu Lembang adalah unik dan menarik. Maka, terdapat sebagian kecil saja pengunjung yang kurang setuju bahwa daya tarik wisata Farmhouse kurang unik.

Dari sebagian kecil pengunjung tersebut jugalah pengunjung yang memiliki komplain terhadap Farmhouse di website tripadvisor.com. Komentar berupa komplain di website tersebut dapat disebabkan oleh kurang variatifnya aktivitas yang dilakukan di Farmhouse. Jumlah pengunjung yang memiliki persepsi negatif juga terbukti dari jumlah kalimat komplain yang di unggah di Instagram pada bulan Maret, yaitu dengan jumlah $2 \%$ saja pada kalimat unggahan. Begitu pula dengan beberapa responden yang memberi nilai kecil pada nilai $1-3$ (sangat tidak unik-cukup unik). Persepsi dipengaruhi oleh faktor internal maupun eksternal individu.

Penulis juga mengamati dari hobi pengunjung yang menyukai olahraga dan hobi lainnya, seperti memasak. Pengunjung dengan hobi atau minat olahraga akan memiliki perbedaan persepsi dengan pengunjung yang menyukai seni atau fotografi.

Pengunjung yang menyukai seni dan fotografi akan menilai bahwa Farmhouse sangat unik untuk kegiatan minat mereka, seperti mengambil foto dan sebagainya. Sedangkan untuk peminat olahraga akan memiliki penilaian yang berbeda yang tidak sebaik penilaian pengunjung dengan minat seni dan fotografi. Dari hasil penilaian yang telah diuraikan tersebut maka hasil perbedaan persepsi tersebut tidaklah jauh berbeda, karena dewasa ini hampir disetiap kalangan masyarakat menyukai kegiatan travelling, terutama berfoto atau yang sering dikenal dengan ber-selfie.

Perbedaan yang nampak pada lebih besarnya nilai persepsi melalui rangsang kalimat dapat disebabkan oleh beberapa alasan. Kalimat yang menarik yang dibaca oleh responden dapat di anggap lebih menarik dibandingkan rangsang melalui gambar/ foto. Hasil tersebut diakibatkan oleh beberapa hal, seperti dalam penelitian ini lebih banyak responden perempuan dibandingkan dengan laki-laki.

Perempuan akan lebih tertarik pada kalimat daripada visual (berupa gambar). Secara umum, laki-laki adalah makhluk visual. Laki-laki lebih tertarik dengan apa yang dilihatnya. Jika apa yang dilihatnya bagus dan menarik, walau mungkin secara substansi tidak terlalu penting atau berguna, ia akan dengan mudah terpikat. Berlawanan dengan perempuan yang umumnya verbal, lebih tertarik dengan kata-kata. Kalimat unggahan dari seluruh sampel dibagi dalam beberapa bentuk kalimat yang semuanya dapat berupa ajakan bagi pembacanya. Dari kalimat tersebut akan muncul persuasi atau ajakan atau bujukan. Persuasi adalah "sebagai tindakan konunikasi yang bertujuan untuk membuat komunikan (penerima pesan) mengadopsi pandangan komunikator (pengirim pesan) mengenai suatu hal atau melakukan suatu tindakan tertentu".

Kalimat unggahan tersebut mengandung persuasi bagi pengunjung/ responden untuk melakukan sesuatu. Pada penelitian ini penulis menetapkan bahwa alasan lebih besarnya penilaian persepsi dengan rangsang kalimat terhadap daya tarik wisata Farmhouse lebih besar, adalah karena perempuan yang lebih banyak sebagai responden, yang pada teorinya perempuan akan cenderung lebih tertarik pada kalimat dibandingkan pada foto/ gambar. Pengunjung prospektif perempuan yang lebih banyak dibandingkan laki-laki akan menilai lebih besar terhadap rangsang kalimat. Maka, dari analisis tersebut penulis beranggapan bahwa banyaknya pengunjung perempuan yang berkunjung ke Farmhouse juga dipengaruhi oleh kalimat unggahan yang berupa ajakan bagi pengunjung.

Persepsi merupakan awal mula individu melakukan suatu tindakan. Pada penelitian ini tindakannya adalah untuk berkunjung ke tempat wisata Farmhouse Susu Lembang. Maka perlu dan penting memperhatikan persepsi daya tarik wisata, sebagai upaya untuk menarik calon 
pengunjung (Pengunjung Prospektif) untuk berkunjung menjadi First Time Visitors bahkan agar seterusnya menjadi Repeat Visitors. Dengan dipelajarinya persepsi maka akan diketahui bagaimana penilaian pengunjung dan mengetahui kemungkinan pengunjung untuk ingin berkunjung kembali Farmhouse Susu Lembang.

\section{KESIMPULAN}

Setelah peneliti melakukan analisis mengenai Perbandingan Persepsi Pengunjung Prospektif dan Pengunjung Pertama Kali Tentang Keunikan Daya Tarik Wisata Farmhouse Susu Lembang, Kabupaten Bandung Barat, maka peneliti menyimpulkan bahwa Farmhouse Susu Lembang adalah Unik.

Dapat dilihat bahwa penilaian pengunjung terhadap Farmhouse Susu Lembang adalah unik, baik penilaian pengunjung prospektif melalui foto dan kalimat unggahan maupun dengan penilaian dari pengunjung yang sudah berkunjung pertama kali. Perbedaannya terdapat dari jumlah skor penilaiannya, dimana penilaian dari pengunjung prospektif lebih besar daripada penilaian pengunjung pertama kali. Dapat diketahui bahwa pengunjung pertama kali memiliki pengalaman berkunjung dan kesan yang kurang baik terhadap Farmhouse Susu
Lembang, yang juga dapat diketahui dari bentuk kalimat komplain di akun Instagram. Hal tersebut dapat disebabkan oleh beberapa hal seperti suasana Farmhouse yang selalu ramai yang dapat menimbulkan ketidaknyamanan bagi pengunjung.

Untuk menghindari kesan yang kurang baik tersebut, maka pengelola dapat melakukan upaya untuk mempertahankan keunikan di Farmhouse Susu Lembang. Dengan menanggulangi kepadatan, terutama saat weekend, sehingga mengurangi persepsi negatif mengenai Farmhouse Susu Lembang yang merupakan daya tarik wisata satusatunya yang bernuansa Eropa di kota Bandung.

\section{DAFTAR PUSTAKA}

Ismayanti. (2010). Pengantar Pariwisata. Jakarta: PT Gramedia Widisarana Indonesia.

Nawawi, Hadari. 2001. Metode Penelitian Bidang Sosial. Gajah Mada University Press, Yogyakarta

Pitana dan Gayatri. (2005). Sosiologi Pariwisata. Yogyakarta: C.V Andi Offset

Sugiyono, (2008). Metode Penelitian Kunatitatif Kualitatif dan $R \& D$. Bandung. Alfabeta

Walgito, Bimo. (2005). Pengantar Psikologi Umum. Yogyakarta: C.V Andi Offset 